\title{
Effect of Soil Coverage on Dual Crop Coefficient of Maize in a Region of Mato Grosso, Brazil
}

\author{
Maria Carolina da Silva Andrea ${ }^{1}$, Francielle Freitas Vieira ${ }^{1}$, Rivanildo Dallacort ${ }^{1}$, João Danilo Barbieri ${ }^{2}$, \\ Paulo Sérgio Lourenço de Freitas ${ }^{2}$, Rafael Cesar Tieppo ${ }^{1}$, Cornelio Alberto Zolin ${ }^{3}$, \\ Willian Krause ${ }^{1} \&$ Diego Fernando Daniel ${ }^{1}$ \\ ${ }^{1}$ State University of Mato Grosso, Tangará da Serra, Mato Grosso, Brazil \\ ${ }^{2}$ State University of Maringá, Maringá, Paraná, Brazil \\ ${ }^{3}$ Embrapa Agrossilvipastoril, Sinop, Mato Grosso, Brazil \\ Correspondence: Maria Carolina da Silva Andrea, State University of Mato Grosso, Tangará da Serra, Mato \\ Grosso, Brazil. E-mail: maria.andrea@usp.br
}

Received: April 22, 2019

doi:10.5539/jas.v11n13p143
Accepted: June 6, 2019 Online Published: August 15, 2019

URL: https://doi.org/10.5539/jas.v11n13p143

\begin{abstract}
With the objective of determining maize's specific water requirements in different soil cover conditions in a Cerrado region of Mato Grosso, Brazil, this study used the dual's crop coefficient (Kc dual) approach, according to FAO methods. An experiment was carried out in 2016, with three treatments: without vegetation soil cover; soil cover of $4 \mathrm{tha}^{-1}$ and soil cover of $8 \mathrm{tha}^{-1}$ dry matter of brachiaria grass. The used methodology accounts for crop's transpiration component (through its basal coefficient, Kcb) and soil evaporation component (through its coefficient, Ke), which were determined for initial, intermediate and final phases of crop development. Experiments were carried in lysimeters to determine crop's evapotranspiration, and in microlysimeters to determine soil evaporation. Crop's transpiration, on three soil coverage treatments, showed overall highest values for the treatment with greater coverage ( $\mathrm{Kcb}$ maximum values of $0.88,1.00$ and 1.03 from the lowest to greater soil coverage), while between crop's phases, coefficient values were always higher at the intermediate stage, presenting decreases with crop senescence. Soil evaporation was highest on treatment without coverage in all crop's stages $(\mathrm{Ke}=0.37-0.78)$ and lowest in the treatment with greater coverage $(\mathrm{Ke}=0.11-0.35)$. Yields were higher on treatments with coverage (9929.18 and $9939.52 \mathrm{~kg} \mathrm{ha}^{-1}$ for treatments with 4 and $\left.8 \mathrm{t} \mathrm{ha}^{-1}\right)$ and lower when cultivated in soil without cover $\left(8264.67 \mathrm{~kg} \mathrm{ha}^{-1}\right)$. Despite relatively higher crop's transpiration with greater soil coverage, this treatment was identified as the best management option in the assessed tropical region of Brazilian Cerrado, in terms of rational use of water, due to lowest losses through evaporation, as also providing the highest grain yields.
\end{abstract}

Keywords: basal crop coefficient, soil water, evaporation coefficient, lysimeter, Zea mays, Cerrado

\section{Introduction}

Maize is one of the most important crops cultivated in Brazil and in its mid-western region, where agricultural activity occupies prominent plance in the economy. The state of Mato Grosso, the largest one of mid-western region, is also the main producer of maize cultivated during the second cropping season, with sowing dates soon after harvesting the summer crop (or first cropping season), which is usually soybean (Silva, Neto, Santos, \& Ceccon, 2013).

Due to the low and irregular distribution of rainfall, the development of maize during the second season can be seriously affected by water stress, resulting in general low yields. As a consequence, there has been a greater interest by region's farmers to invest in irrigation systems, since this practice reduces climatic risks and provides yield increases (Silva, Vanzela, Vazquez, \& Sanches, 2012). Irrigated agriculture presents itself as an important alternative for the process of verticalization of agricultural production It can provide not only water throughout the crop cycle, but it also allows the enlargement of sowing windows due to the possibility of water supplementation when drought periods happen within the rainy season ("veranicos") (Souza, Lima, Carvalho, Rocha, \& Silva, 2011). However, Faggion, Oliveira, Chistofidis and Faggion et al. (2009) affirm that this practice is only profitable and sustainable when carried out in a rational way, without causing economic and 
environmental impacts. Thus, it is fundamental to adopt practices that favor the increase of the efficiency of water use to increase the productivity of the crops.

The state of Mato Grosso has 67,071 hectares of irrigated area, presenting a growth of $117.3 \%$ from 2006 to 2013, according to the National Agency of Waters [ANA] (ANA, 2013). Although Brazil is the third country worldwide in terms of irrigation potential, it is necessary to perform a rational irrigation management, providing adequate water application to each crop, according to the water requirements for each phase of its development, according to the Food and Agriculture Organization of the United Nations [FAO] (FAO, 2013).

Determining when and how much to irrigate each crop is a crucial factor for the optimization of water resources and obtaining a higher economic return of the irrigated crop (Wagner, Jadoski, Maggi, Saito, \& Lima, 2013). A widely used tool for accurate quantification of crop water consumption is the use of crop coefficient (Kc). The Kc accurately shows the water consumption of the plant according to each phenological phase, allowing to estimate the need for irrigation, preventing excess and water scarcity, meeting plant's specific needs and providing reduction of water wastes (Faria, Campeche, \& Chibana, 2006; Ferreira, Pavani, \& Bastos, 2013; Santos, Sobrinho, Medeiros, Moura, \& Nunes, 2014). For the determination of Kc, crop's evapotranspiration (Etc) is determined and divided per potential evapotranspiration (ETo). Considering that ETo represents the evaporative demand of the atmosphere, Kc represents the magnitude with which the crop meets this demand. Therefore, the determination of precise values of Kc for the different crops has great importance when dealing with crop's water requirement. The most recommended manner to perform this is to relate ETc measured by weighing lysimeters with estimated ETo from meteorological station data through the Penman-Monteith method (Allen, Pereira, Raes, \& Smith, 1998).

However, to improve the efficiency of measurement of water consumption from plants in field conditions, FAO 56 defined that Kc can be fractionated into two parameters, which allows a detailed study of the quantification of evaporated water from the soil and transpired water by the plant. This approach relies on the determination of soil evaporation coefficient (Ke), determined by the ratio between soil evaporation (E) and ETo; and on the determination of the basal crop coefficient $(\mathrm{Kcb})$, determined by the ratio between plant transpiration $(\mathrm{T})$ and ETo. Thus, $\mathrm{Kc}$ dual is calculated by the sum of $\mathrm{Kcb}$ and $\mathrm{Ke},(\mathrm{Kc}$ dual $=\mathrm{Kcb}+\mathrm{Ke})$ (Allen et al., 1998). Several studies have employed FAO methodology of Kc dual, wether on a single basis (Liu \& Luo, 2010), adapting its methodology (Ding et al., 2013) or even working together with water balance models (Martins et al., 2013; Zhao et al., 2013), all with good accuracy results. In general, these studies aim to improve water conservation issues and irrigation water management, pointing to its environmental and economical importance.

If in humid conditions, where there is no transpiration limitation, the environmental factor that may change evaporation rate is the soil cover during crop growth and the soil cover by organic residues on top soil (Martins et al., 2013), as in no-till systems (Dalmago et al., 2010). Considered a conservationist practice, soil cover changes the soil-water relationship, maintaining its moisture for a longer period of time, contributing to reduce the process of soil water loss through evaporation, as well as providing improvements in soil structure, reducing soil erosion and compaction, due to the increase in the organic matter content and improvement of soil microbiota. Thus, soil coverage can contribute to reduce the frequency of irrigation, besides providing increase of agricultural productivity and being economic more sustainable (Andrioli \& Mello, 2012; Cardoso, Silva, Carvalho, Freitas, \& Avanzi, 2013). Therefore, studies aiming to quantify the rate of evaporation in certain quantities of straw are necessary to better assess the magnitude with which condition of soil coverage provides the most suitable results.

Considering the above, the objective of this study was to determine the influence of soil cover on the Kc dual of maize in a southeast region of the State of Mato Grosso.

\section{Method}

The experiment was carried out in the experimental area of the State University of Mato Grosso-UNEMAT, Campus of Tangará da Serra, at the area of the Center for Research, Studies and Agri-Environmental Development-CPEDA, in the Agrometeorology Laboratory in 2016.

At the experimental area, geographic coordinates of $14^{\circ} 65^{\prime} 00^{\prime \prime} \mathrm{S}$ and $57^{\circ} 43^{\prime} 15^{\prime \prime} \mathrm{W}$ and at 440 meters of altitude, there is an automatic meteorological station (Campbell Scientific) installed with a Data Logger CR1000, performing data storage every 15 minutes. Hourly data of time, temperature, relative humidity, rainfall, solar radiation, wind speed and atmospheric pressure were used in the present study.

The study area presents a well defined dry season between May and September and a rainy season between October and April. The average annual rainfall is of $1,830 \mathrm{~mm}$ and the annual average temperature is of $24.5^{\circ} \mathrm{C}$ 
(Dallacort et al., 2011). Local soil is classified as Red Latosol, with a very clayey texture, according to the Brazilian Company of Farming Research [EMBRAPA] (EMBRAPA, 2013).

Six high precision lysimeters with an area of $2.25 \mathrm{~m}^{2}(1.50 \times 1.50 \mathrm{~m})$ and $1.20 \mathrm{~m}$ depth were used in the determination of crop evapotranspiration (ETc). The lysimeters were previously calibrated, according to Faria et al. (2006), with the aim of establishing the relationship between the signal emitted by the load cell (mv) and the mass oscillation of the set $(\mathrm{kg})$, which occurs through evapotranspiration, irrigation, rainfall and drainage. The observed hysteresis values were $0.08 ; 0.02 ; 0.04 ; 0.05 ; 0.04$ and $0.06 \mathrm{~mm}$, respectively, for lysimeters $1 ; 2 ; 3 ; 4$; 5 and 6. Nascimento et al. (2011) evaluating the accuracy of a set of weighing lysimeters using the same sensor model observed minimum values of hysteresis without significant effect.

Maize was sown manually on July $20^{\text {th }} 2016$, in the six lysimeters. At the border of the plots a no-tillage seeder was used. Maize was also cultivated in the soil outside the lysimeter, totaling $1600 \mathrm{~m}^{2}$ of experimental area. The spacing between rows was of $0.45 \mathrm{~m}$ with 2.7 plants per linear meter, and a population of 60,000 plants per hectare. The genetic material used was AG 7088 RR, characterized by being a simple hybrid of early maturity cycle. All plants in the lysismiters were manually harvested, 116 days after sowing. The obtained was adjusted to kilograms per hectare $\left(\mathrm{kg} \mathrm{ha}^{-1}\right)$.

The experiment comprised three treatments with two replicates: soil cultivated with maize, uncovered (T1), soil cultivated with maize and $4 \mathrm{t} \mathrm{ha}^{-1}$ of Brachiaria straw as soil cover (T2) and soil cultivated with maize and $8 \mathrm{t}$ $\mathrm{ha}^{-1}$ of Brachiaria straw as soil cover (T3). The forage, Brachiaria brizantha, after being collected in the dependencies of the University, was maintained in forced circulation air oven at temperature of $65^{\circ} \mathrm{C}$ until reaching constant mass weight. Plant cover was uniformly arranged on the lysimeter soil 14 days after crop emergence. The association between lysimeters and treatments (i.e., determination of which lysimeter would receive which treatment) was randomly performed, wherein each treatment was assigned to two lysimeters (Figure 1).

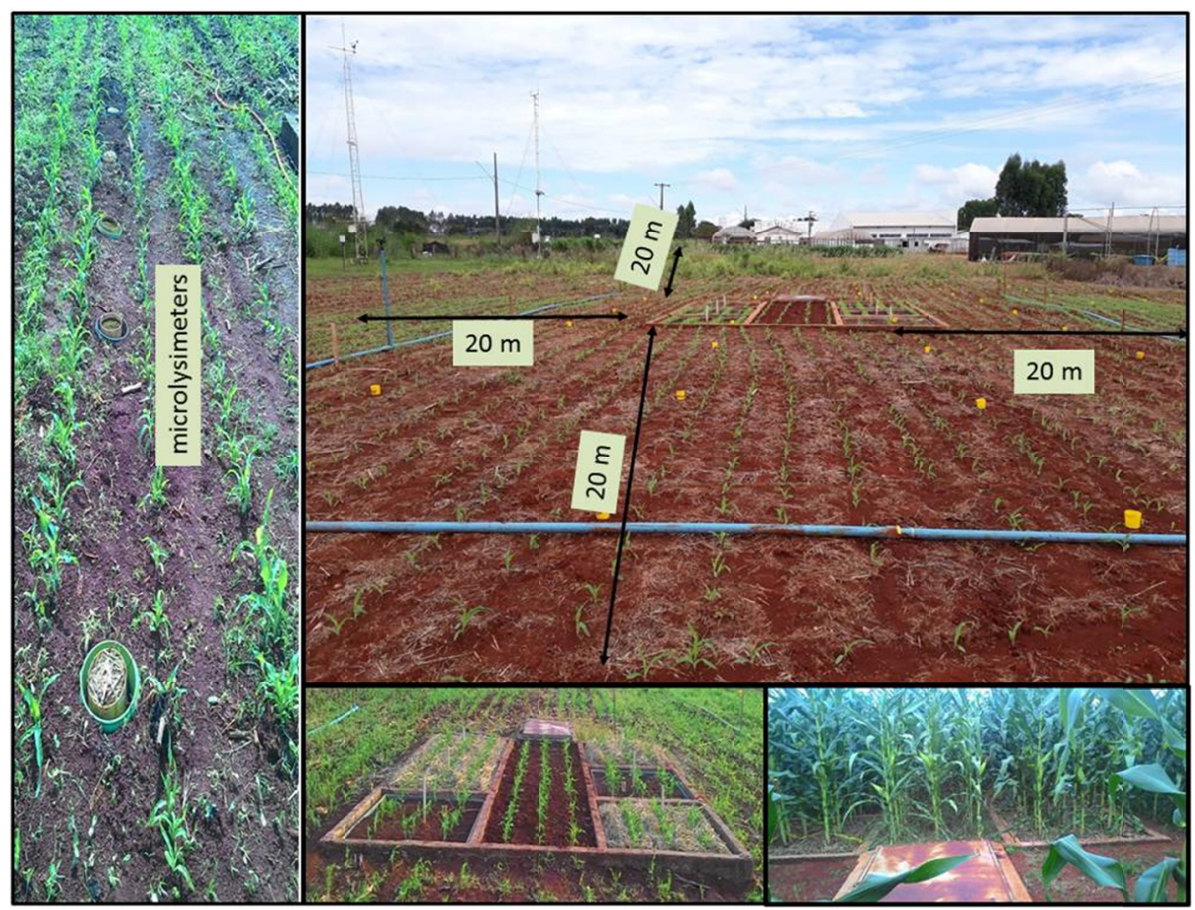

Figure 1. Maize experiments in weighing lysimeters and different amounts of forage straw as soil cover

Fertilization was performed according to soil chemical analysis (Table 1). According to the result of the analysis, there was no need to perform application of lime. Fertilization consisted of $45 \mathrm{~kg}$ of $\mathrm{K}_{2} \mathrm{O}$ and $95 \mathrm{~kg}$ of $\mathrm{P}_{2} \mathrm{O}_{5}$, applied in the sowing line. A total of $314 \mathrm{~kg}$ of $\mathrm{N}$ (as urea) was applied, split into three applications, one at sowing and two cover applications: one at V4 stage and other at the V8 stage of crop development. 
Table 1 . Soil chemical analysis in the $0-20 \mathrm{~cm}$ depth of the experimental area at UNEMAT in Tangará da Serra-MT

\begin{tabular}{|c|c|c|c|c|c|c|c|c|c|c|c|c|}
\hline Sample & $\mathrm{pH}$ & $P$ & $\mathrm{~K}$ & $\mathrm{Ca}+\mathrm{Mg}$ & $\mathrm{Ca}$ & $\mathrm{Mg}$ & $\mathrm{Al}$ & $\mathrm{H}$ & $\mathrm{S}$ & CTC & $\mathrm{V}$ & O.M. \\
\hline & $\mathrm{H}_{2} \mathrm{O}$ & $--N$ & $\mathrm{DM}^{-3}--$ & ----- & --.-. & --- cn & $\mathrm{lc} \mathrm{dm}$ & --- & ---- & --- & $\%$ & $\mathrm{~g} \mathrm{dm}^{-3}$ \\
\hline 1 & 5.3 & 4.7 & 77.2 & 1.75 & 1.25 & 0.5 & 0.35 & 4.42 & 8.1 & 6.72 & 29.02 & 28.7 \\
\hline
\end{tabular}

Note. *AGROANÁLISE-Laboratory, Cuiabá-MT (May/2016).

Irrigation was performed using a sprinkler irrigation system, composed of 6 sprinklers (model Eco 232, Fabrimar, Rio de Janeiro, Brazil), with a service pressure of 30 m.c. and spaced $12 \times 12 \mathrm{~m}$ between emitters and lateral lines, respectively. The system presented a Christiansen Coefficient of Uniformity of $86 \%$ and an irrigation intensity of $9.76 \mathrm{~mm} \mathrm{~h}^{-1}$. Irrigation depth was calculated according to the need to restore water to the plants. This necessity was obtained by means of the variation of water storage in the soil of the weighing lysimeters. The irrigation shift was always performed after 6:00 p.m. to avoid interference with the measured evapotranspiration from the lysimeters.

For the determination of maize crop evapotranspiration (ETc) throughout the cycle, the load cell readings were obtained from records with a 5 second frequency of measurement and 15 minutes frequency of data storage. Data collection started at 15 days after crop emergence, and the brachiaria straw was arranged in the lysimeters on the $14^{\text {th }}$ day after emergence of maize, totalizing 97 days of data collection during the crop cycle. The negative variation of the mass of the lysimeters in a given period of time corresponds to the amount of water lost to the atmosphere, as presented in Equation 1:

$$
\text { Etc }=\left(\mathrm{M}_{\mathrm{i}}-\mathrm{M}_{\mathrm{i}-1}\right) / \mathrm{A} \times \Delta \mathrm{t}
$$

where, Etc: crop evapotranspiration ( $\mathrm{mm} \mathrm{period}^{-1}$ ); $\mathrm{M}_{\mathrm{i}}$ : current lisymeter mass; $\mathrm{M}_{\mathrm{i}-1}$ : previous lisymeter mass; $\mathrm{A}$ : lisymeter area; $\Delta \mathrm{T}$ : time period.

In a normal day (absence of rainfall or irrigation) it is expected that negative values of mass variation occur because current values are always smaller than the mass values of the previous occurrence. Therefore, the negative values are expressed by the water output of the system and positive values as input of water by irrigation or rainfall.

The methodology of Penman-Monteith, proposed by Allen et al. (1998), was used for the calculation of the reference evapotranspiration-Eto, according to Equation 2:

$$
\text { Eto }=0.408 \cdot \Delta \cdot(\mathrm{Rn}-\mathrm{G})+\gamma \cdot[900 /(\mathrm{Tm}+273)] \cdot \mathrm{U}_{2}(\mathrm{es}-\mathrm{ea}) / \Delta+\gamma \cdot(1+0.34 \mathrm{U} 2)
$$

where, ETo: reference evapotranspiration $\left(\mathrm{mm} \mathrm{day}^{-1}\right)$; Rn: Net solar radiation on crop $\left(\mathrm{MJ} \mathrm{m}^{-2} \mathrm{day}^{-1}\right)$; G: soil heat flux density o $\left(\mathrm{MJ} \mathrm{m}^{-2}\right.$ day $\left.^{-1}\right) ; \mathrm{Tm}$ : air temperature at $2 \mathrm{~m}$ above soil $\left({ }^{\circ} \mathrm{C}\right) ; \mathrm{U}_{2}$ : air velocity at $2 \mathrm{~m}$ above soil $\left(\mathrm{m} \mathrm{s}^{-1}\right)$; es: vapor saturation pressure $(\mathrm{kPa})$, which was estimated through the average of es of Tmax and es of Tmin; ea: current vapor pressure $(\mathrm{kPa})$; es - ea: pressure deficit and vapor saturation $\left(\mathrm{kPa}^{\circ} \mathrm{C}^{-1}\right)$; $\Delta$ : vapor pressure curve $\left(\mathrm{kPa}^{\circ} \mathrm{C}^{-1}\right)$ e $\gamma$ : psychometric constant $\left(\mathrm{kPa}^{\circ} \mathrm{C}^{-1}\right)$.

After obtaining data from the lysimeters and the meteorological station, the ETc and the ETo were calculated. Through the ratio between both evapotranspiration values, the Kc value was obtained by Equation 3 .

$$
\mathrm{Kc}=\mathrm{Etc} / \mathrm{ETo}
$$

where, Kc: single crop coefficient.

For the determination of the soil evaporation coefficient, nine microlisymeters of $150 \mathrm{~mm}$ diameter and $300 \mathrm{~mm}$ height were used, located in the border of the experimental plots at 5 meters of distance from the weighing lysimeters, to determine soil evaporation and evaporation coefficient of the soil (Ke) daily, according to the methodology proposed and adapted from Flumignan, Faria, and Lena. (2012).

Data collection from the microlysimeers was performed daily and at the same time, at 6:00 a.m. and 6:00 p.m. hours, by means of manual weighing in a precision scale. Due to the period during which the experiment was carried out, there were no occurrences of rains with an intensity greater than $20 \mathrm{~mm}$ and there was no possibility of saturation of the microlysimeters, although some irrigations reached a leaf of $30 \mathrm{~mm}$ in the initial phase of the culture, the microlysimeters were removed from the area to avoid possible saturation.

Soil evaporation was determined in millimeters (LMS), as according to Equation 4:

$$
\mathrm{E}_{\mathrm{ML}}=\Delta \mathrm{M}_{\mathrm{ML}} / \mathrm{A}_{\mathrm{ML}}+\mathrm{P}
$$


where, $\mathrm{E}_{\mathrm{ML}}$ : microlysimeter evaporation $(\mathrm{mm}) ; \Delta \mathrm{M}_{\mathrm{ML}}$ : mass variation of microlysimeters $(\mathrm{kg}) ; \mathrm{A}_{\mathrm{ML}}$ : microlysimeter area $\left(\mathrm{m}^{2}\right)$; P: rainfall $(\mathrm{mm})$.

Ke represents the relationship between soil evaporation (in $\mathrm{mm}$ ) and reference evapotranspiration, obtained at daily step, according to Equation 5:

$$
\mathrm{Ke}=\mathrm{E}_{\mathrm{ML}} / \mathrm{ETo}
$$

where, Ke: Coefficient of soil evaporation.

The determination of $\mathrm{Kc}_{\text {dual }}$ originated from two other coefficients: the basal coefficient of crop (Kcb) and $\mathrm{Ke}$, following the methodology proposed by FAO-56 (Allen et al., 1998), according to Equation 6.

$$
\mathrm{Kcb}=\mathrm{ETc} / \mathrm{ETo}-\mathrm{Ke}
$$

where, Kcb: Basal coefficient of crop.

For the estimation of $\mathrm{Kcb}$ and $\mathrm{Ke}$, standardized methodology from FAO was employed:

$$
\mathrm{Kcb}=\mathrm{Kcb}_{\text {(tab) }}+\left[0.04\left(\mathrm{u}_{2}-2\right)-0.004(\mathrm{RHmin}-45)\right] \times(\mathrm{h} / 3)^{0.3}
$$

where, $\mathrm{Kcb}_{\text {(tab) }}$ : value for $\mathrm{Kcb}_{\text {half }}$ or $\mathrm{Kcb}_{\text {final }}$ (if $\geq 0.45$ ) originated from Table 17 of $\mathrm{FAO} 56 ; \mathrm{u}_{2}$ : daily wind average speed at $2 \mathrm{~m}$ of heigth over standard vegetation (grass) during intermediate or final stage $\left[\mathrm{m} \mathrm{s}^{-1}\right]$ for $1 \mathrm{~m}$ $\mathrm{s}^{-1} \leq \mathrm{u}_{2} \geq 6 \mathrm{~m} \mathrm{~s}^{-1}$; RHmin: average value of minimum daily relative humidity during intermediate and final stages [\%] para $20 \% \leq$ RHmin $\geq 80 \%$; h: average value of plant height during intermediate and final stages [m] (Table 12 of FAO 56 ) for $20 \% \leq$ RHmin $\geq 80 \%$.

Considering the water evaporation from the soil, there are two main situations, (i) when the soil is wet (by irrigation or rainfall) soil evaporation happens at maximum rate, but the crop coefficient $(\mathrm{Kc}=\mathrm{Kcb}+\mathrm{Ke})$ can never exceed the maximum value, $\mathrm{Kc}_{\max }$, determined by the available energy for soil surface evapotranspiration $\left(\mathrm{Kcb}+\mathrm{Ke} \leq \mathrm{Kc}_{\max }\right)$ or $\mathrm{Ke} \leq\left(\mathrm{Kc}_{\max }-\mathrm{Kcb}\right)$; and (ii) when the soil surface dries, less water is available for evaporation and a reduction in evaporation begins to occur proportionally to the amount of water remaining in the soil surface layer (Equation 8).

$$
\mathrm{Ke}=\mathrm{Kr}\left(\mathrm{Kc}_{\max }-\mathrm{Kcb}\right) \leq \text { few } \mathrm{Kc}_{\max }
$$

where, $\mathrm{Kc}_{\text {max }}$ : maximum $\mathrm{Kc}$ value after rainfall or irrigation; $\mathrm{Kr}$ : coefficient of reduction of evaporation dependent on the cummulative amount of depletive water (evaporated) of soil surface; few: surface soil fraction evaporation.

For the determination of Kcb and Ke coefficients, crop's phenological phases were observed at field conditions according to FAO-56 (Allen et al., 2006), where: I) initial phase: from planting to $10 \%$ of soil coverage (sowing-emergence); II) growth phase: from the end of the initial phase to $80 \%$ of the soil coverage (tasseling-flowering); III) intermediate phase: from $80 \%$ of the soil coverage to the beginning of maturation, (production- grain filling); IV) final stage: from the beginning of physiological maturity to harvest (maturity-harvest). Number of days for each phase occurred from the development of crop in the field experiments.

\section{Results and Discussion}

The daily rainfall, irrigation, and average temperatures from sowing to harvest are presented in Figure 2. Rainfall and irrigation were of 262.02 and $595.48 \mathrm{~mm}$, respectively, totaling an amount of $857.5 \mathrm{~mm}$ during the growing period. Cruz et al. (2010) reported that maize requires a total of $600 \mathrm{~mm}$ of water, while the ideal range for the crop, according to Santos et al. (2014), is considered to vary from 400 to $700 \mathrm{~mm}$. This large variation due to water needs is due to aspects of sowing season, crop cycle and atmospheric demand of each region (Silva et al., 2012). Therefore, the sum of the precipitated water volume and that provided by irrigation during the period of conduction of the experiment, meet the water requirement of the crop. 


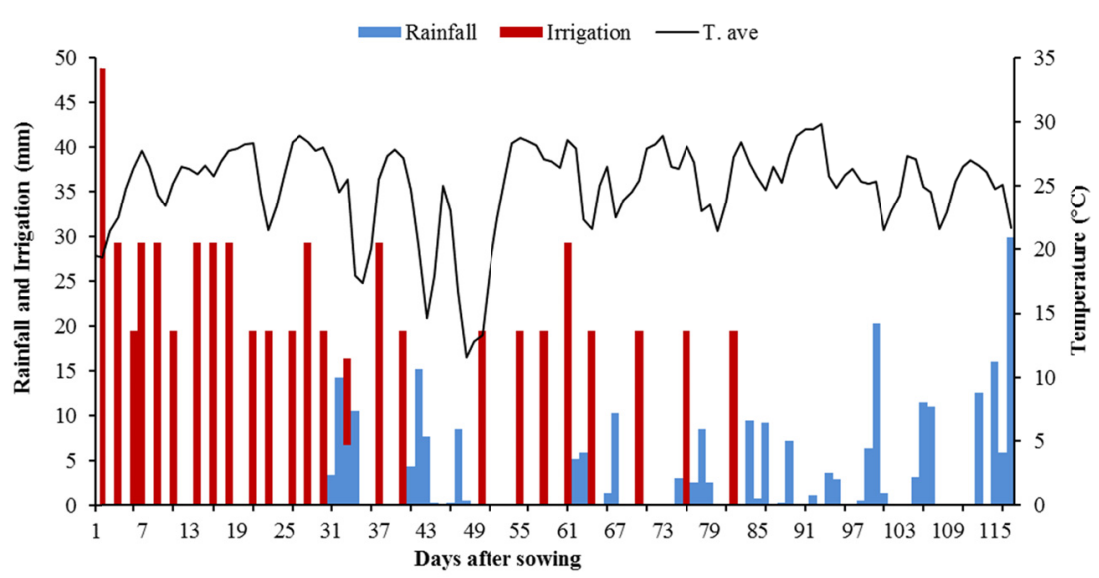

Figure 2. Irrigation, rainfall and average air temperature from maize sowing to harvest in Tangará da Serra-MT

During the crop cycle, average air temperature was of $24.87^{\circ} \mathrm{C}$, values within the recommended temperature range for maize, which according to Murga-Orrillo et al. (2016), and should be around $25{ }^{\circ} \mathrm{C}$. There is a direct relationship between rainfall and air temperature; on days when rainfall occurred, average air temperature was reduced. These results corroborate with those obtained by Fenner et al. (2016) where the maize harvest in October presented average temperature of $25.29^{\circ} \mathrm{C}$.

Daily values of ETo and ETc during the study period, for T1, T2 and T3 (maize crop without soil cover, cultivation with 4 and with $8 \mathrm{tha}^{-1}$ of soil cover, respectively) are shown in Figure 3. ETo values ranged from 0.60 and $5.69 \mathrm{~mm} \mathrm{day}^{-1}$, with an average of $3.41 \mathrm{~mm} \mathrm{day}^{-1}$, totalizing $330.87 \mathrm{~mm}$ for the analyzed period. The measure of accumulated ETc was of $389.44 \mathrm{~mm}$, with a maximum value of $7.25 \mathrm{~mm}^{-1 a y^{-1}}$, minimum of 0.68 $\mathrm{mm}$ day $^{-1}$ and average of $3.97 \mathrm{~mm} \mathrm{day}^{-1}$. These values are close to those that are usually found in studies determining ETo and ETc in maize. Souza, Lima and Carvalho, (2012) determined the evapotranspiration of the crop and found $3.46 \mathrm{~mm}_{\text {day }}{ }^{-1}$ in the state of Rio de Janeiro and Sobenko, Fanaya Júnior, Santos and Marques., (2016) found values $2.61 \mathrm{~mm} \mathrm{day}^{-1}$ for the state of Mato Grosso, the same of the present study.

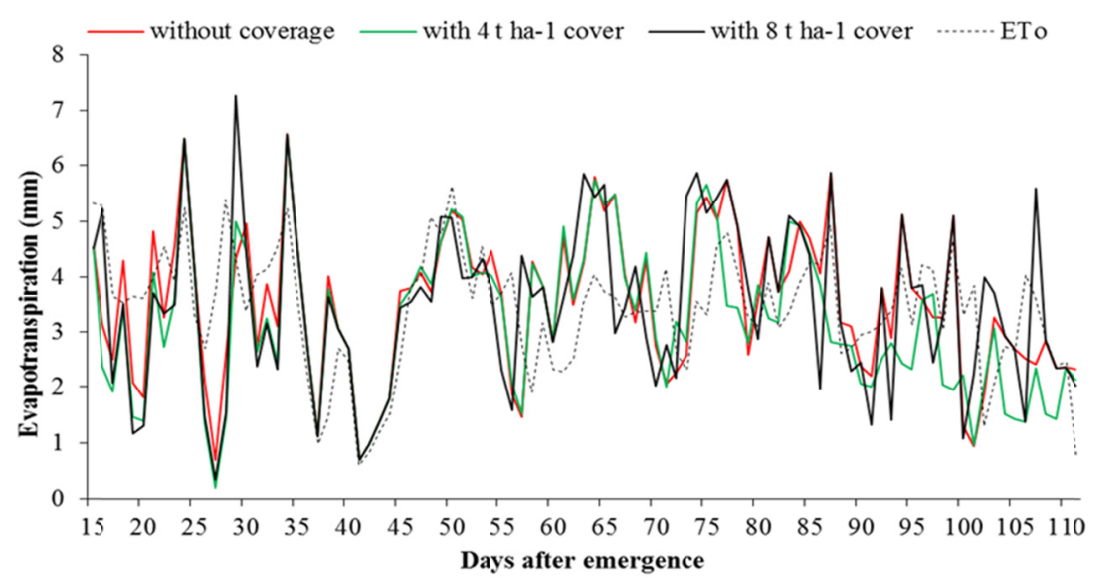

Figure 3. Daily values of ETo and ETc for the treatments without soil cover, cultivation with 4 and with 8 tha $^{-1}$ of soil cover for maize cropping period in Tangará da Serra-MT

The accumulated ETc in T1 was of $340.47 \mathrm{~mm}$, with a maximum of $6.58 \mathrm{~mm} \mathrm{day}^{-1}$, minimum of $0.69 \mathrm{~mm} \mathrm{day}^{-1}$ and average of $3.51 \mathrm{~mm}^{-1 a y}{ }^{-1}$; in T2 the total accumulated was of $309.14 \mathrm{~mm}$, with a maximum of $6.56 \mathrm{~mm}$ day $^{-1}$, a minimum of $0.2 \mathrm{~mm}_{\text {day }}{ }^{-1}$ and average of $3.19 \mathrm{~mm} \mathrm{day}^{-1}$. In the treatment with the greatest amount of straw (T3), the accumulated ETc was of $336.57 \mathrm{~mm}$, with maximum of $7.27 \mathrm{~mm}^{-1}{ }^{-1}$, minimum of $0.34 \mathrm{~mm}$ day $^{-1}$ and average of $3.47 \mathrm{~mm}^{\text {day }}{ }^{-1}$. 
Values close to these were found by Santos et al. (2014), during a cycle length of 77 days of the cultivation of green maize, hybrid AG 1051, in the semi-arid region of Rio Grande do Norte, northeastern Brazil, with maximum values of ETo of $5.45 \mathrm{~mm}_{\text {day }}{ }^{-1}$, minimum of $3.07 \mathrm{~mm}^{-1} \mathrm{day}^{-1}$, totalizing $344.90 \mathrm{~mm}$. The ETc varied between $1.94 \mathrm{~mm}_{\text {day }}{ }^{-1}$ to $5.68 \mathrm{~mm} \mathrm{day}^{-1}$, and presented a total of $300.54 \mathrm{~mm}$, measured by weighing lysimeters in a conventional tillage system. In a study with the hybrid Eldorado (115 days of cycle) in the municipality of Seropédica-RJ, Souza et al. (2012) determined ETc by weighing lysimetry and obtained a cumulative total of $394.00 \mathrm{~mm}$. These ETc values are close to those obtained in this study; however the regions present influences of the different edaphoclimatic conditions.

The difference between the accumulated ETc between T1 and T3 was $3.84 \mathrm{~mm}$, however, the dynamics in the water use between these treatments was different. While the evaporation component of the soil remained high in relation to the transpiration component of the plant in T1, in T3 it was verified a lower evaporation of the soil and greater transpiration of the plant. This fact is explained by the greater availability of water in the soil to the plants, increasing plant transpiration in $\mathrm{T} 3$ when compared to $\mathrm{T} 1$.

As for crop's coefficients, this inverse behavior between treatments without soil cover and with $8 \mathrm{tha}^{-1}$ can be observed in Figure 4, where the daily Kcb and Ke curves for the crop are presented. For the treatment without soil cover (Figure 3A), in the initial phase (from 1 to 30 days after emergence, DAE) and in the development phase (from 31 to 70 DAE) Ke presented higher values than Kcb, already in the intermediate phase (71 to 95 DAE). In the beginning of the final phase of the crop (96 to 110 DAE), Ke and Kcb showed an inverse relationship, where Ke values reduced and $\mathrm{Kcb}$ values increased. Approximately $105 \mathrm{DAE}$, period that comprises the final phase of the crop, the Kcb reduced again and the Ke increased due to the senescence of the leaves, as a function of the physiological maturity of the plant. 

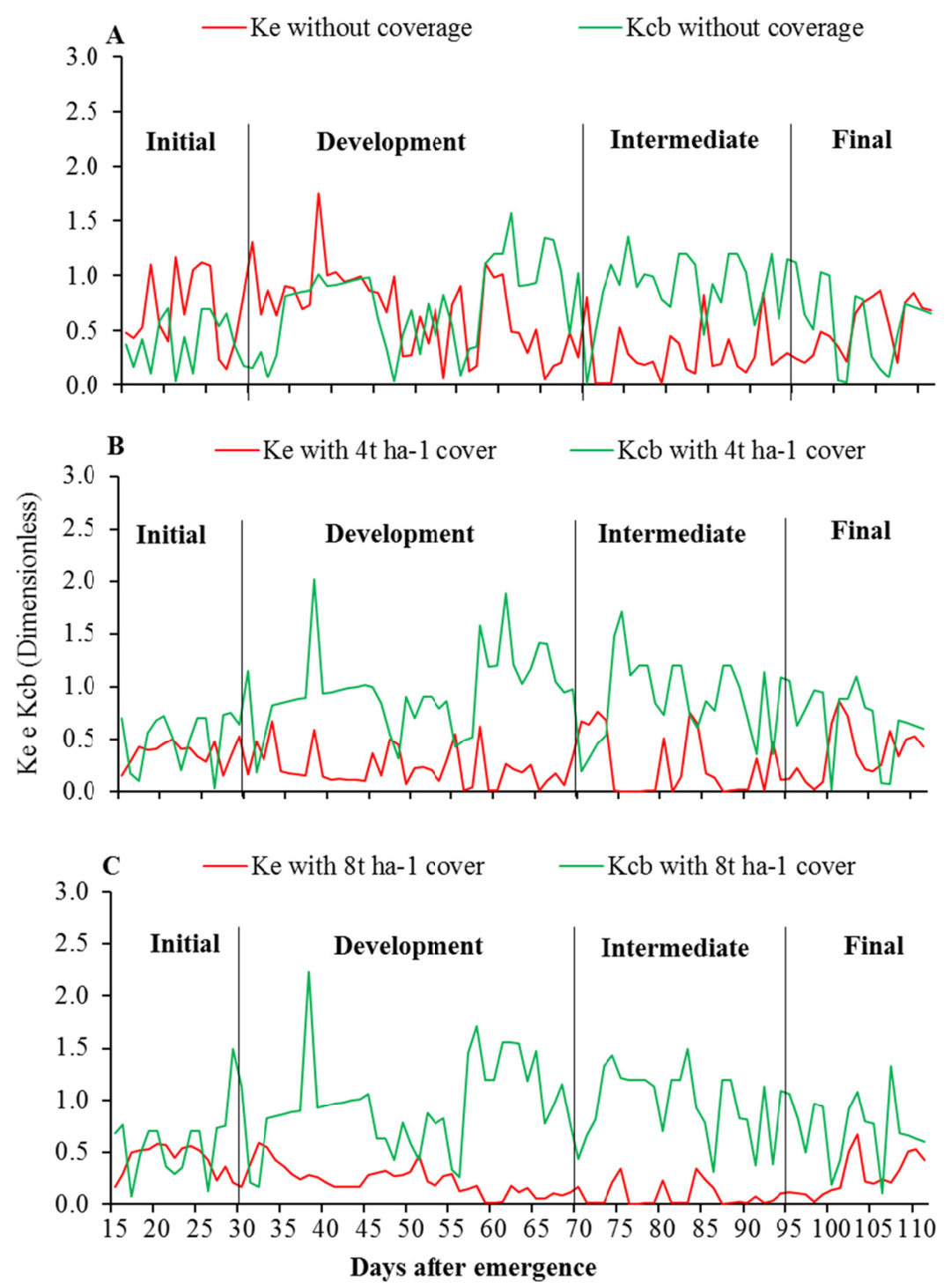

Figure 4. Evaporation coefficient (Ke) and basal coefficient of maize $(\mathrm{Kcb})$ for the treatments without soil cover (Figure 3A), cultivation with $4 \mathrm{tha}^{-1}$ (Figure 3B) and with $8 \mathrm{t} \mathrm{ha}^{-1}$ (Figure 3C) of soil cover for maize cropping period in Tangará da Serra-MT

In the treatments with 4 and $8 \mathrm{tha}^{-1}$ of brachiaria soil cover (Figures 3B and 3C), respectively, the observed behavior was the inverse of that one observed in T1, wherein both the initial, intermediate and final stages of development of the crop, values of Ke were smaller than the values of Kcb. According to Santos et al. (2014), the use of soil cover reduces the evaporation process, especially at the stages where the canopy of the plants does not fully cover the soil, ie the initial stage of development of the crop. Martins et al. (2013), using Kc dual methodology on a model-basis, evaluating different irrigation methods in covered $\left(\sim 3 \mathrm{t} \mathrm{ha}^{-1}\right)$ cropped soil with maize on a no-till system in Southern Brazil, found little variation in the coefficients due to water application methods. The latter authors showed the greatest importance of soil evaporation component at the beginning of crop cycle, even at their cooler climate conditions.

Regarding the relationship between Ke and Kcb, as occurred in T1, it was observed higher Ke values when compared to Kcb, during the initial crop phase until the end of its development. Since the leaf area index is low at the beginning of the crop growth cycle, and the soil is not fully covered, it is exposed to solar radiation which contributes to a more intense evaporation (Fenner et al., 2016).

During the intermediate phase of the crop the opposite occurred, the Kcb reached maximum value since the plant is in its full development, decreasing by the final crop phases, due the senescence of the leaves, since the leaf is the main responsible for the physiological processes of the plant, including transpiration (Allen et al., 1998). 
Fenner et al. (2016) determined the dual coefficient for beans in conventional tillage systems for a nearby region and found similar results of the $\mathrm{Kcb}$ and $\mathrm{Ke}$ ratio between the initial, intermediate and final development stages.

In Figure 5 the comparison between values of Ke and Kcb for the treatments without soil cover and with 4 and 8 $t \mathrm{th}^{-1}$ of brachiaria can be observed. The treatments with soil cover provided lower values of Ke, justified by the fact that the evaporation of the water from the soil depends on the availability of energy and water, and its coverage constitutes a physical barrier, reducing the direct incidence of solar radiation, also the main source of energy used in the evaporation process (Gasparim, Ricieri, Silva, Dallacort, \& Gnoatto, 2005).

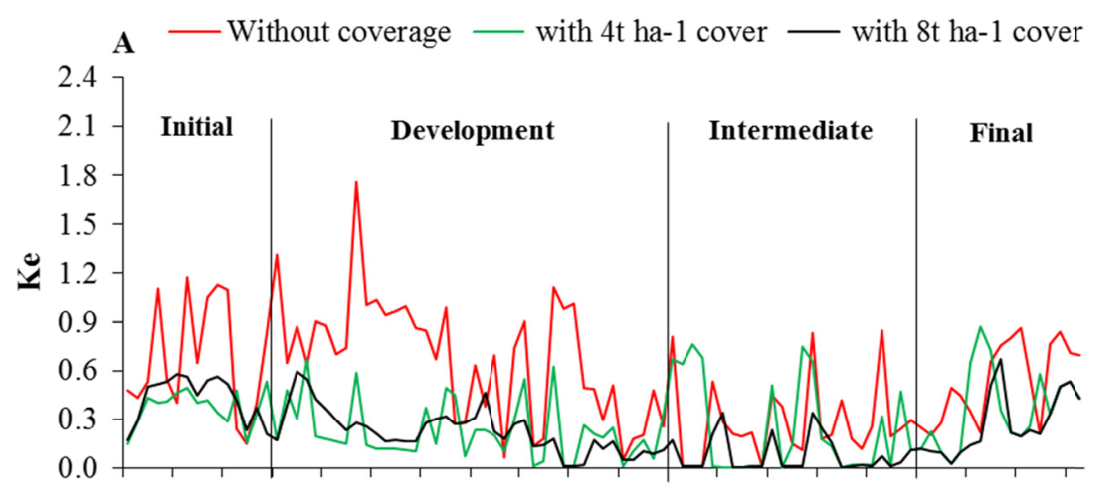

B

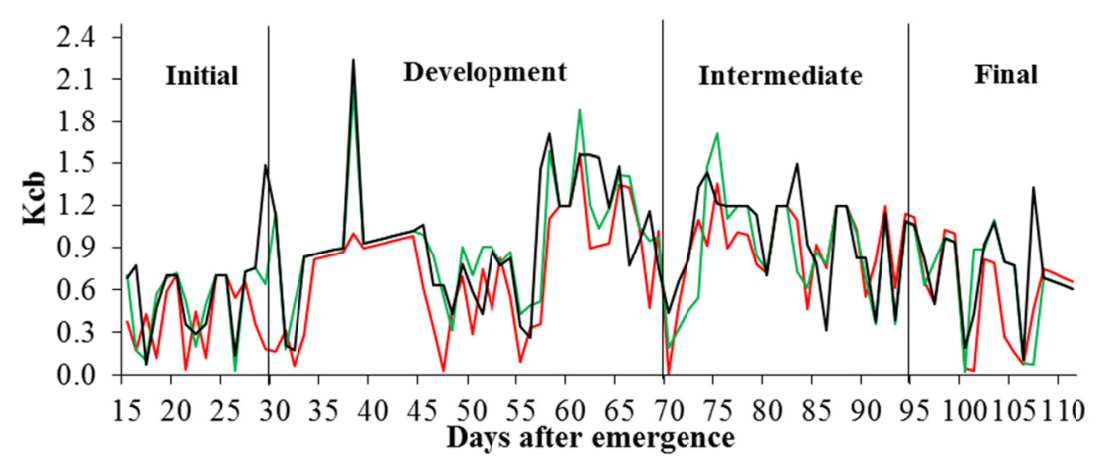

Figure 5. Soil evaporation coefficient (Ke) (Figure 4A) and basal coefficient of maize (Figure 4B) for the treatments without soil cover (Figure 3A), cultivation with $4 \mathrm{t} \mathrm{ha}^{-1}$ (Figure 3B) and with $8 \mathrm{t} \mathrm{ha}^{-1}$ (Figure 3C) of soil cover for maize cropping period in Tangará da Serra-MT

The Ke coefficient in the treatment without soil cover showed a daily average of 0.55 and a total of 53.42 ; treatment with $4 \mathrm{t} \mathrm{ha}^{-1}$ coverage presented a daily average was 0.28 and a accumulated total of 26.84; and the treatment with $8 \mathrm{tha}^{-1}$ coverage presented daily average of 0.23 , totalizing 21.95 (Figure 5A). The evaporation of the soil water was strongly reduced by the presence of soil cover, resulting in a reduction in the values of Ke, since the cover acts as a thermal insulation, intercepting the solar rays and making it difficult for the soil to absorb energy, maintaining it with humidity for a longer period of time (Gava, Freitas, Faria, Rezende, \& Frizzone, 2013).

The Kcb without soil cover showed a daily average of 0.70 , and a total of 67.92 ; treatment with $4 \mathrm{tha}^{-1}$ coverage presented daily average of 0.82 and a cumulative total of 79.78 and the treatment with $8 \mathrm{t} \mathrm{ha}^{-1}$ of coverage presented a daily average of 0.86 and a total of 83.73 (Figure 5B). These data justify the ETc values found in the treatment without cover and in the treatment with $8 \mathrm{tha}^{-1}$ of brachiaria coverage, with small differences found between both. However, in the treatment without coverage Ke values were higher, and in contrast Kcb values were lower, while for treatment with $8 \mathrm{tha}^{-1}$ coverage the opposite occurred. Therefore, soil cover changed the dynamics of water use in maize cultivation.

Liu and Luo (2010), working with Kc dual and weighing lysimiters, highlight a good overall tendency prediction of the FAO method, but point to some inaccuracy in the "peak" values (as can be observed in Figures 4 and 5 of the present study), indicating a probable overestimation at those peaks and at the end stages of crop cycle, an 
underestimation at the initial stages of crop cycle and some inaccuracy also when dealing with short-term periods, e.g. of a few days. The latter authors found less accurate results for maize when compared to wheat.

Zhao et al. (2013), also working with Kc dual on a model-basis and microlysimiters, found an overall good agreement between simulated and observed soil moist data for wheat ad maize, although they did not use weighing lysimeters. The use of Kc dual approach on a model-basis is a promising application to automatize irrigation management with good accuracy on crop's demands (Ding et al., 2013)

The measured $\mathrm{Kcb}$ presented lower values than estimated in all treatments and in all stages of crop development, as can be observed in Table 2. These differences are acknowledged and may be related to climate, soil and the hybrid used (Allen et al., 1998). Liu and Luo (2010) stated that Kc dual provided better agreement of crop's coefficients for wheat and summer maize when compared to lysimeter data.

Table 2. Basal coefficient of maize (Kcb) and soil evaporation coefficient $(\mathrm{Ke})$ measured in weighing lysimeters and estimated by FAO 56 method for Tangará da Serra-MT

\begin{tabular}{|c|c|c|c|c|c|c|c|c|c|}
\hline \multirow{2}{*}{ Phases } & \multirow{2}{*}{ DAE } & \multirow{2}{*}{$\mathrm{Kcb}$} & \multirow{2}{*}{$\mathrm{Ke}$} & \multicolumn{2}{|c|}{ Without cover } & \multicolumn{2}{|c|}{$4 \mathrm{t} \mathrm{ha}^{-1}$ cover } & \multicolumn{2}{|c|}{$8 \mathrm{t} \mathrm{ha}^{-1}$ cover } \\
\hline & & & & $\mathrm{Kcb}$ & $\mathrm{Ke}$ & $\mathrm{Kcb}$ & $\mathrm{Ke}$ & $\mathrm{Kcb}$ & $\mathrm{Ke}$ \\
\hline & & \multicolumn{2}{|c|}{----- Estimated ----- } & \multicolumn{6}{|c|}{ 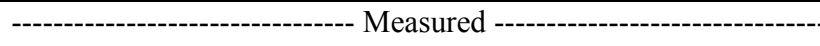 } \\
\hline Initial & $1-30$ & 0.75 & 0.48 & 0.39 & 0.71 & 0.62 & 0.43 & 0.67 & 0.44 \\
\hline Development & $31-70$ & 1.09 & 0.12 & 0.74 & 0.66 & 0.93 & 0.24 & 0.93 & 0.22 \\
\hline Intermediate & $71-95$ & 1.20 & 0.01 & 0.94 & 0.26 & 0.92 & 0.22 & 1.00 & 0.08 \\
\hline Final & $96-110$ & 0.96 & 0.12 & 0.54 & 0.55 & 0.66 & 0.38 & 0.71 & 0.28 \\
\hline Average & & 1.00 & 0.18 & 0.65 & 0.55 & 0.78 & 0.32 & 0.83 & 0.26 \\
\hline
\end{tabular}

Regarding Ke coefficient, its behavior was inversed to that found for Kcb. In addition, greater differences were observed between their measured and estimated data (Table 2), indicating a greater tendency of soil variability as a function of texture and humidity. Thus, the quantity of soil water, influenced by the effects of soil cover, can promote major changes and variability in evaporation values (Gava et al., 2013).

Similar trends to those obtained in this study were observed by Fenner et al. (2016), in which the measured Kcb values were lower than those observed in all stages of bean development, while the observed values of Ke were always higher than the estimated values. According to these authors, such differences can be attributed to the specific characteristics of the genetic material and the peculiarities of the regional climate, which may provide greater demand for evapotranspiration in the region.

Regarding fractions of $\mathrm{Kc}$ by $\mathrm{Kcb}$ and $\mathrm{Ke}$, respectively, the treatment without soil cover presented 55.97 and $44.02 \%$, the treatment with $4 \mathrm{t} \mathrm{ha}^{-1}$ of soil coverage presented $74.82 \%$ and $25.17 \%$, and the treatment with $8 \mathrm{t}$ $\mathrm{ha}^{-1}$ of soil coverage presented 79.22 and $20.77 \%$. While cultivating beans without soil cover in the same region of the present study, in Tangará da Serra-MT, Fenner et al. (2016) found the fractions of Kc by Kcb and Ke, respectively, of 58.21 and $41.79 \%$, pointing to the relationship of these values dependent on the crop.

Comparison of absolute values of crop coefficients with other studies should be done carefully. Regions hardly have exact same climate, soil and crop conditions, and the wide range of climatic types impose varied plant and atmosphere water demands, ultimately representing varied values of crop's coefficients across their cycles. However, the general tendency of high soil evaporation in the beginning of crop cycle and the high plant transpiration in the end of crop cycle is unanimous, regardless region and climate type (Ding et al., 2013; Martins et al., 2013; Zhao et al., 2013).

For the present study, we were able to compare and quantitfy the magnitude of variation of evaporation and transpiration among different conditions of soil coverage in a tropical Cerrado condition. The treatment with larger amount of soil coverage provided greater water conservation in the assessed conditions, even with the higher plant transpiration. In practical terms, considering a planted area of 100 hectars of maize, with an average ETo of $3.41 \mathrm{~mm} \mathrm{day}^{-1}$, as in the assessed region, and the average Kc dual for uncovered, covered with 4 and with $8 \mathrm{tha}^{-1}$ of brachiaria of $1.25 ; 1.10$ and 1.09 , respectively, about 56,265,000 liters of water would be saved using $4 \mathrm{tha}^{-1}$ of coverage, while $60,016,000$ liters of water could be saved when using $8 \mathrm{tha}^{-1}$ of coverage.

Maize productivity was also influenced by the use of soil cover; treatments that had coverage also had the highest yields, with values of 8264.67; 9929.18 and $9939.52 \mathrm{~kg} \mathrm{ha}^{-1}$ for the treatments without soil cover, with 4 and $8 \mathrm{t} \mathrm{ha}^{-1}$ of brachiaria cover, respectively. Thus, the straw provided less water evaporation from the soil, 
making this resource available for cultivation and favoring its development, as stated by higher transpiration and crop yields.

\section{Conclusions}

During initial phases of crop development, the treatment without soil cover stands out from the rest with the highest evaporation rates.

Overall, the larger the amount of soil coverage, the higher was maize's transpiration rates and the lower was the soil evaporation rates.

Intermediate phase of crop development presented the highest transpiration and lowest soil evaporation rates in all soil cover treatments, indicating the importance of proper water management to achieve high yield levels.

Greater transpiration and lower soil evaporation rates resulted in relatively higher yields for the treatment with 8 $\mathrm{t} \mathrm{ha}^{-1}$ of soil cover.

The treatment with largest amount of soil cover was identified as the best option to provide a relatively more ration use of water, while obtaining higher yields.

\section{References}

ANA (National Agency of Waters). (2013). Projeto Pivôs Brasil. Retrieved from http://arquivos.ana.gov.br/ imprensa/noticias/20150304031651_Projeto_Pivos_-_Resumo_2013.pdf

Allen, R. G., Pereira, L. S., Raes, D., \& Smith, M. (1998). Crop evapotranspiration: Guidelines for computing crop requirements. Irrigation and Drainage Paper, 56(1), 300.

Andrioli, I., \& Mello, P. R. (2012). Plantas de cobertura em pré-safra e adubação nitrogenada na fertilidade do solo em diferentes camadas, cultivado com milho em sistema de plantio direto e convencional. Semina: Ciências Agrárias, 33(3), 963-978. https://doi.org/10.5433/1679-0359.2012v33n3p963

Cardoso, D. P., Silva, M. L. N., Carvalho, G. J., Freitas, D. A. F., \& Avanzi, J. C. (2013). Espécies de plantas de cobertura no recondicionamento químico e físico do solo. Revista Brasileira de Ciências Agrárias, 8(3), 375-382. https://doi.org/10.5039/agraria.v8i3a2421

Cruz, J. C., Filho, I. A. P., Alvarenga, R. C., Neto, M. M. G., Viana, J. H. M., Oliveira, M. F.,... Filho, M. R. A. (2010). Cultivo do milho. Sistema de Produção. EMBRAPA. Retrieved from http://www.cnpms.embrapa. br/publicacoes/milho_6_ed/manejomilho.htm

Dallacort, R., Martins, J. A., Inoue, M. H., Freitas, P. S. L., \& Coletti, A. J. (2011). Distribuição das chuvas no município de Tangará da Serra, médio norte do Estado de Mato Grosso, Brasil. Acta Scientiarum. Agronomy, 33(2), 193-200. https://doi.org/10.4025/actasciagron.v33i2.5838

Dalmago, G. A., Bergamaschi, H., Kruger, C. A. M. B., Bergonci, J. I., Comiran, F., \& Heckler, B. M. M. (2010). Evaporação da água na superfície do solo em sistemas de plantio direto e preparo convencional. Pesquisa Agropecuária Brasileira, 45, 780-790. https://doi.org/10.1590/S0100-204X2010000800002

Ding, R., Kang, S., Zhang, Y., Hao, X., Tong, L., \& Du, T. (2013). Partitioning evapotranspiration into soil evaporation and transpiration using a modified dua crop coefficient model in irrigated maize field with ground-mulching. Agricultural Water Management, 127, 85-96. https://doi.org/10.1016/j.agwat.2013. 05.018

EMBRAPA. (2013). Sistema brasileiro de classificação dos solos (p. 306). Brasília: EMBRAPA.

Faggion, F., Oliveira, C. A. S., \& Chistofidis, D. (2009) Uso eficiente da água: Uma contribuição para o desenvolvimento sustentável da agropecuária. Pesquisa Aplicada \& Agrotecnologia, 2(1), 187-190.

Faria, R. T., Campeche, F. D. S. M., \& Chibana, E. Y. (2006). Construção e calibração de lisímetros de alta precisão. Revista Brasileira de Engenharia Agrícola e Ambiental, 10(1), 237-242. https://doi.org/10.1590/ S1415-43662006000100035

Fenner, W., Dallacort, R., Freitas, P. S. L., Júnior, C. A. F., Carvalho, M. A. C., \& Bariviera, G. (2016). Dual crop coefficient of common bean in Tangará da Serra, Mato Grosso. Revista Brasileira de Engenharia Agrícola e Ambiental, 20(5), 455-460. https://doi.org/10.1590/1807-1929/agriambi.v20n5p455-460

Ferreira, J. O. P. P., Pavani, L. C., \& Bastos, E. A. (2013). Coeficientes de cultura para a melancieira irrigada por gotejamento no vale do Gurgueia-PI. Irriga, 18(3), 509-521. https://doi.org/10.15809/irriga.2013v18n3p509 
Flumignan, D. L., Faria, R. T. De., \& Lena, B. P. (2012). Test of a microlysimeter for measurement of soil evaporation. Engenharia Agrícola, 32(1), 80-90. https://doi.org/10.1590/S0100-69162012000100009

FAO (Food and Agriculture Organization of the United Nations). (2013). Statistical Yearbook (p. 307). Retrieved from http://www.fao.org/docrep/018/i3107e/i3107e.PDF

Gasparim, E., Ricieri, R. P., Silva, S. L., Dallacort, R., \& Gnoatto, E. (2005). Temperatura no perfil do solo utilizando duas densidades de cobertura e solo nu. Acta Scientiarum. Agronomy, 27(1), 107-115. https://doi.org/10.4025/actasciagron.v27i1.2127

Gava, R., Freitas, P. S. L., Faria, R. T., Rezende, R., \& Frizzone, J. A. (2013). Soil water evaporation under densities of coverage with vegetable residue. Engenharia Agrícola, 33(1), 89-98. https://doi.org/10.1590/ S0100-69162013000100010

Junior, C. E. G., Medeiros, J. F., Melo, T. K., Espinola Sobrinho, J., Bristot, G., \& Almeida, B. M. (2013) Necessidade hídrica da cultura do girassol irrigado na chapada do Apodi. Revista Brasileira de Engenharia Agrícola e Ambiental, 17(3), 261-267. https://doi.org/10.1590/S1415-43662013000300003

Liu, Y., \& Luo, Y. (2010). A consolidated evaluation of the FAO-56 dua crop coefficient approach using the lysimeter data in the North China plain. Agricultural Water Management, 97, 31-40. https://doi.org/ 10.1016/j.agwat.2009.07.003

Martins, J. D., Rodrigues, G. C., Paredes, P., Carlesso, R., Oliveira, Z. B., Knies, A. E., ... Pereira, L. S. (2013). Dual crop coefficients for maize in southern Brazil: Model testing for sprinkler and drip irrigation and mulched soil. Biosystems Engineering, 115, 291-310. https://doi.org/10.1016/j.biosystemseng.2013.03.016

Murga-Orrillo, H., Araújo, W. F., Abanto-Rodriguez, C., Sakazaki, R. T., Bardales-Lozano, R. M., \&Polo-Vargas, A. R. (2016). Influência da cobertura morta na evapotranspiração, coeficiente de cultivo e eficiência de uso de água do milho cultivado em cerrado. Irriga, 21(2), 352-364. https://doi.org/10.15809/ irriga.2016v21n2p352-364

Nascimento, E. F., Campeche, L. F. S. M., Bassoi, L., Silva, J. A., Lima, A. C. M., \& Pereira, F. A. C. (2011) Construição e calibração de lisímetros de pesagem para determinação da evapotranspiração e coeficiente de cultivo em videiras de vinho cv. Syrah. Irriga, 16(3), 271-287. https://doi.org/10.15809/ irriga.2011v16n3p271

Rosa, R. D., Paredes, P., Rodrigues, G. C., Fernando, R. M., Alves, I., Pereira, L. S., \& Allen, R. G. (2012). Implementing the dual crop coefficient approach in interactive software: 2. Model testing. Agricultural Water Management, 103, 62-77. https://doi.org/10.1016/j.agwat.2011.10.018

Santos, W. O., Sobrinho, J. E., Medeiros, J. F., Moura, M. S. B., \& Nunes, R. L. C. (2014). Coeficientes de cultivo e necessidades hídricas da cultura do milho verde nas condições do semiárido brasileiro. Irriga, 19(4), 559-572. https://doi.org/10.15809/irriga.2014v19n4p559

Silva, J. F., Neto, A. L., Santos, A., \& Ceccon, G. (2013). Morfofisiologia de milho safrinha em espaçamento reduzido e consorciado com Urocloa ruziziensis. Revista Agrarian, 6(21), 259-267.

Silva, M. R., Vanzela, L. S., Vazquez, G. H., \& Sanches, A. C. (2012). Influência da irrigação e cobertura morta do solo sobre as características agronômicas e produtividade de milho. Irriga, 1(1), 170-180. https://doi.org/ 10.15809/irriga.2012v1n01p170

Souza, A. P., Lima, M. E., \& Carvalho, D. F. (2012). Evapotranspiração e coeficientes de cultura do milho em monocultivo e em consórcio com a mucuna-cinza, usando lisímetros de pesagem. Revista Brasileira de Ciências Agrárias, 7(1), 142-149. https://doi.org/10.5039/agraria.v7i1a802

Souza, A. P., Lima, M. E., Carvalho, D. F., Rocha, I. O., \& Silva, L. B. D. (2011). Umidade do solo e vegetação espontânea em diferentes coberturas mortas submetidas a lâminas de irrigação. Revista Brasileira de Ciências Agrárias, 6(1), 127-139. https://doi.org/10.5039/agraria.v6i1a668

Sobenko, L. R., Fanaya Júnior, E. D., Santos, O. N. A., \& Marques, P. A. A. (2016). Estimativa da necessidade de irrigação na cultura do milho safrinha em Sorriso-MT por métodos agroclimatológicos. Revista Brasileira de Milho e Sorgo, 15(3), 543-556. https://doi.org/10.18512/1980-6477/rbms.v15n3p543-556

Wagner, M. V., Jadoski, S. O., Maggi, M. F., Saito, L. R., \& Lima, A. S. (2013). Estimativa da produtividade do milho em função da disponibilidade hídrica em Guarapuava, PR, Brasil. Revista Brasileira de Engenharia Agricola e Ambiental, 17(2), 170-179. https://doi.org/10.1590/S1415-43662013000200008 
Zhao, N., Liu, Y., Cai, J., Paredes, P., Rosa, R. de., \& Pereira, L. S. (2013). Dual crop coefficient modelling applied to the winter wheat-summer maize crop sequence in North China Plain: Basal crop coefficients and soil evaporation component. Agricultural Water Management, 117, 93-105. https://oi.org/10.1016/ j.agwat.2012.11.008

\section{Copyrights}

Copyright for this article is retained by the author(s), with first publication rights granted to the journal.

This is an open-access article distributed under the terms and conditions of the Creative Commons Attribution license (http://creativecommons.org/licenses/by/4.0/). 